Article

\title{
Writing Disability into Colonial Histories of Humanitarianism
}

\author{
Paul van Trigt ${ }^{1, *}$ and Susan Legêne ${ }^{2}$ \\ ${ }^{1}$ Institute for History, Leiden University, 2311 BE, Leiden, The Netherlands; E-Mail: p.w.van.trigt@hum.leidenuniv.nl \\ 2 Department of History, VU University Amsterdam, 1081 HV, Amsterdam, The Netherlands; E-Mail: s.legene@vu.nl \\ * Corresponding author
}

Submitted: 29 June 2016 | Accepted: 1 September 2016 | Published: 10 November 2016

\begin{abstract}
In this paper, the relation between humanity and disability is addressed by discussing the agency of people with disabilities in colonial histories of humanitarianism. People with disabilities were often-as indicated by relevant sources-regarded and treated as passive, suffering fellow humans, in particular in the making and distribution of colonial photography. In the context of humanitarianism, is it possible to understand these photographs differently? This paper analyzes one photograph-from the collection of the Tropenmuseum Amsterdam-of people with leprosy in the protestant leprosarium Bethesda, in the Dutch colony Suriname, at the beginning of the twentieth century. It discusses the way the sitters in the photograph have been framed, and how the photograph has been made and used. The photograph makes it difficult to register agency, but easily reaffirms existing colonial categories. Therefore, this paper also uses another strategy of analysis. By following Actor-Network Theory, focusing on non-human actors, the second part of this paper offers a new and more convincing interpretation of the photograph. This strategy (a) understands agency as a phenomenon of interdependence instead of independence, and (b) approaches photographs as both real and performed. Combining the written history of humanitarianism and disability, it allows new histories of people with disabilities to develop, histories that move beyond the categories of colonialism.
\end{abstract}

\section{Keywords}

actor; Actor-Network Theory; agency; colonialism; disability; humanitarianism; leprosy; photography

\section{Issue}

This article is part of the issue "Humanity as a Contested Concept: Relations between Disability and 'Being Human'”, edited by Paul van Trigt (Leiden University, The Netherlands), Alice Schippers (Disability Studies in Nederland, The Netherlands) and Jacqueline Kool (Disability Studies in Nederland, The Netherlands).

(C) 2016 by the authors; licensee Cogitatio (Lisbon, Portugal). This article is licensed under a Creative Commons Attribution 4.0 International License (CC BY).

\section{Introduction}

With the adoption of the UN Convention on the Rights of People with Disabilities (CRPD) (2006) the world community officially acknowledged that people with disabilities are equal in terms of their humanity and place in society. In general, disability activists welcome the convention because it enables the global inclusion and situational improvement of people with disabilities. With this framing of disability as a human rights issue, disability becomes part of the "humanitarian cloud", prompting organized efforts on behalf of others based on the notion of a shared humanity (Laqua, 2014, p. 175). Although clouds are flexible, the "humanitarian cloud" is and was often determined by the dichotomy of active (Western) helpers acting on behalf of passive (non-Western) sufferers (Hutchison, 2014, p. 12). This dichotomy is being questioned from a postcolonial perspective-for instance, by Gyan Prakash (1994) - as well as from a disability studies perspective (Meekosha, 2011). "Nothing about us, without us" summarizes the overarching program of the disability rights movement (Charlton, 1998), which emphasizes the agency of people with disabilities. Their intervention requires further reflection with respect to the "humanitarian cloud" around human rights. This is the more pertinent since, as Mark Philip Bradley 
has argued in the US context, popular American commitment to human rights was often preceded and accompanied by stories and pictures of fellow humans suffering (Bradley, 2014; cf. Musarò, 2015).

In this paper, we link the postcolonial and disability studies perspectives by asking the following question, "How do people with disabilities figure in the history of the "humanitarian cloud", and how can their histories be known? Are these separate histories, running parallel to "mainstream" history, just as a leprosarium was a colony within the colony, or do their histories interfere in and change history at large?" In the historiography about humanitarianism and human rights, people with disabilities receive little explicit attention, which is also the case in (post)colonial historiography. The history of people with disabilities in the (former) colonies is in its infancy (Brégain, 2016). There may be strong reasons for this: since disability, as understood in the West, is not always articulated in the same way in non-Western contexts, it is not certain that a disability approach to history makes sense in histories of colonialism (cf. Livingstone, 2006; Maxwell, 2008). When we follow, however, an intersectional approach-adding disability to our conceptual toolbox as a category like race and gender (Kudlick, 2003) - we may be able to investigate whether and how sources from colonial times depict the intersection of these categories in the making of the colonial context.

If we try to imagine a humanitarian history of disability-in, for example, the case of leprosy (Vongsathorn, 2012) - we will likely find that, because of the dominant perspective of sources, the history depicts people with disabilities as passive sufferers. People with leprosy often entered the colonial archive only as the inhabitants of leprosariums, receiving the benefits of progressive medical research and religious care. Of course, historians have found alternative ways to write about the history of leprosy that undermine this preconceived idea of people with disabilities as passive (Buckingham, 2002), and that support the aim of disability history-part of the emancipatory field of disability studies - to present, represent, give voice to, and restore historical agency to people with disabilities (Kudlick, 2003; Longmore \& Umansky, 2001). However, this image of people with disabilities as passive sufferers is hardly undermined by an analysis of visual sources, whereas, in the historiography of humanitarian photography, disability is not addressed (Fehrenbach \& Rodogno, 2015; Lydon, 2016).

Here we come across a central problem in colonial history. In a recent article about the representation of human suffering in post-colonial exhibitions, we discussed a Dutch exhibition of photographs that "explicitly show rows of Indonesian rural village (desa) people who have been executed by the soldiers under Dutch command". We saw the potential of these photographs to "trigger debates on law, justice, reparation", but also questioned whether displaying the dead bodies of desa people who had been killed, and thus effectively made the "last" passive victims of the Dutch empire, was a way to leave ethnographic photography behind and acknowledge these people as historical citizens of a postcolonial state to come (Legêne, 2014). We take up this question again -in the case of people with disabilities, whose images figure in the "humanitarian cloud" - and ask, "How can their history be written beyond their image as silent sufferers?"

This paper will explore possible answers to this question through analysis of a photograph of people with leprosy in colonial Suriname. The photograph is part of the collection of the Tropenmuseum - the former Dutch Colonial Museum-in Amsterdam and the Royal Netherlands Institute of Southeast Asian and Caribbean Studies. The photograph-as a historical source-is relevant for three reasons. In the first place, photographs are an important source in the history of the "humanitarian cloud". Visual materials often have been produced and used to serve campaigns for humanitarian relief and human rights. Secondly, this photograph, made in the context of leprosy care in Suriname, enables us to investigate the possible intersection of disability, race, gender and religion, and the multiple affinities and distinctions that put the disabled in their designated place within the colonial hierarchy. Although we focus on leprosy, we do not want to suggest that people with leprosy can represent all people with disabilities in the colonies. However, the case of leprosy is relatively well documented, and is therefore a good starting point for writing disability into humanitarian histories of colonialism. Finally, a photograph from a museum collection in the data cloud helps us consider how historians and museum professionals might intervene in the dominant essentializing and ahistorical reproduction of colonial images of people with disabilities in public histories, for instance by reconsidering the captions that "document" - in the language of their time-these photographs.

This paper investigates whether and how the historical agency of people with disabilities can be recognized in modern visual sources, and what this recognition would mean for writing histories of disability in the "humanitarian cloud" from a disability studies perspective. This paper, therefore, is mainly about methodology, especially because disability history's aim of "granting agency" to people with disabilities (Kudlick, 2013) needs-in our opinion-an alternative. In the first part, this paper analyzes the photograph described above through a method proposed by anthropologist Elisabeth Edwards to investigate colonial photography. Edwards (2001, p. 20) distinguishes three "defining moments" of a photograph: 1) the arrangement of the setting (or the framing), 2) the making of the photograph, and 3 ) the usage (or the circulation) of the printed image. Such an analysis enables us, as will be demonstrated, to combine strategies developed by scholars like Stoler (2009), Roque and Wagner (2012), Jordanova (2012), and Legêne (2013) to trace the agency of the "colonized". Nevertheless, it appearsas will become clear below-difficult to register agency or break through the silence. Historiography about pho- 
tography may need other concepts (cf. Edwards, 2016). Moreover, existing categories of (dis)ability seem reaffirmed when we follow the special biography of the photograph in its moments of framing, making, and circulation. Therefore, in the second part of this paper, an additional method is explored: the so-called Actor-NetworkTheory (ANT). ANT approaches the research object or actor as embedded in a network of relations between humans and non-humans (Latour, 2005). Moreover, ANT enables us to approach the photograph as both made and real (cf. M'Charek, 2010), and as co-existing with other realities. We apply ANT in a heuristic way when analysing the photograph, and argue that this method has the potential to be used for writing the history of people with disabilities in the "humanitarian cloud" without reaffirming the image of a disabled person as passive and colonized.

\section{Description of the "Others" Within}

The extensive historical literature about people with leprosy in the colonies provides an essential context for analysing the photograph here discussed. In the quest to locate agency, it is important to know that people with leprosy in the colonial era were-because of their leprosy and the colonizers' fear of infection-"othered" in a way that was beyond the "othering" treatment generally accorded colonised peoples, and in the corresponding humanitarian discourse. They had to live in places that were separated from the rest of society (as "others within", see Roque \& Wagner, 2012, p. 15; cf. Stoler, 2009), often referred to as leper colonies. For this case study, we have chosen such a colony: Bethesda, a protestant leprosarium in Suriname, founded in the 18th century, modernized at the end of the 19th century and closed in 1968 (Van Hilte-Rustwijk \& Van Steenderen-Rustwijk, 2003; cf. Menke \& Menke, 2013; Snelders, in press). Bethesda's history between 1879 and 1928 has been written by Jacqueline Postma (2003).

The photograph we will focus on (see Figure 1), was made between 1897 and 1915. In the picture, we see eleven people on the veranda of a house, on what seems to be a sunny day. Four are white European women, attired in long dresses, two of whom wear a straw hat with a ribbon. Seven people are black, mostly young men, Surinamese men. One of them is standing, like the four women. The other six sit on chairs and benches in a half circle around a piece of leather. Most of them wear an apron and have a tool, shoe, or a bristle in their hands; one of them is sitting be-

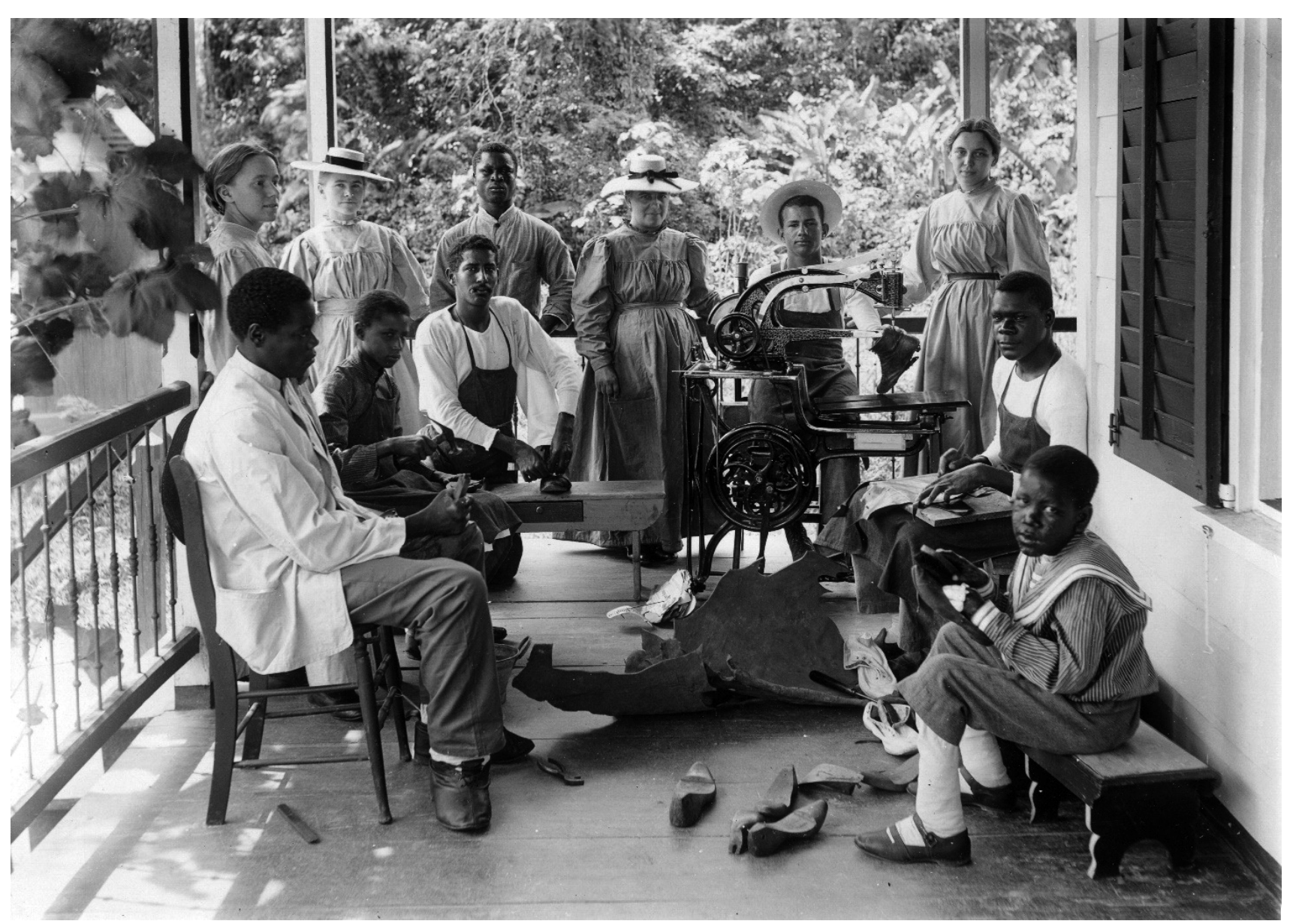

Figure 1. Shoemakers and staff at New Bethesda, Suriname, before 1915. Collection H.W. Bosman. Photographer unknown (Augusta Curiel). Photograph Courtesy National Museum of World Cultures (TM-10019121). 
hind a shoe stitching machine. One young man, orbetter-a boy, has his hand bandaged, and one man is wearing special sized shoes; the boy and the man with the special sized shoes are nearest the camera, and are therefore clearly visible. Seven people are looking in the camera, three are looking in another direction, and one man turns his gaze down. (Collection National Museum of World Cultures. Object nr. TM-10019121. Copy of original dry gelatine glass negative. See also www.collectie.wereldculturen.nl and look for "Schoenmakers in de leprozenkolonie Nieuw Bethesda". The same photograph is in the Image collection of KITLV, (http://media-kitlv.nl) collection number 7655).

Can we understand this photograph as a depiction of agency of the "others within"? As was said, we could recognize the dominant image of people with leprosy who are isolated by exclusion within a colonial context; but is this actually what is at stake in this photograph? In this photograph, the people with leprosy, their tools, and their working materials are center stage. The European women-nurses of Bethesda and, probably, in the middle, the Director's wife-enclose the group. The four women and the man who stands, maybe a supervisor, do not perform a role; they seem there only at the request of the photographer. Their position in the photograph suggests they do not suffer from leprosy. The sitting men re-enact their craft; they seem to stop working only for the moment the photograph is taken. Their position in the photograph suggests they have leprosy indeed. We suspect the photographer has staged the arrangement because a veranda was not often used as a working place, and because the number of men seems more than needed for the number of shoes and the size of the piece of leather, but-in this photograph-the men are working men. So, in this photograph, it is not immediately clear who is the "other" because no act of "othering" can be observed. In fact, we should doubt whether a preconceived framing of people within the colonies as "others" (cf. Stoler, 2009) helps us analyse the photograph.

\section{Framing, Making and Circulating}

First, we have a closer look at how this picture is framed; that-according to Edwards-is the first defining moment of the photograph (2001, p. 20). The veranda, the garden, and the wall of the house frame the image. The stair, balcony fencing, and wooden pillars indicate that the veranda is above ground level. But we do not see the wider world to which this particular place and particular people belong, which makes clear that Bethesda is a closed off place on the margins of Surinamese society. People with leprosy were expected-or forcedto live apart. Bethesda was a microcosm in itself. The nurses were part of the community, but had more freedom of movement since they were not infected with leprosy. As we turn our attention within the frame of the photograph, the presence of nurses and shoemakers un- derlines a difference we know from the wider worldnamely the difference between white colonizers and black colonised-as well as (we come back to this later) a difference between abled and disabled people. To depict people with leprosy at work, the presence of nurses is-strictly speaking-unnecessary. The nurses are not skilled shoe makers, but they volunteered to be part of this photograph, or the photographer invited them because-without them-the picture would be incomplete. People with leprosy need supervision, the photograph seems to suggest. The nurses' presence within the frame limits our ability to see the shoemakers as independent, to see their agency.

What can we learn about agency from the second defining moment, the making of the photo? The identity of the photographer is unknown. Because of the photograph's quality, and because there exist comparable photographs of other aspects of Bethesda from the beginning of the twentieth century, it seems likely that the management of Bethesda hired a professional photographer like Augusta Curiel-who also made photographs of Bethesda, which circulated as post cards - to make their project visible (Van Dijk, Van Petten-van Charante, Van Putten, \& de Jonge, 2007; Weiss, 1915). Regardless, there seems no real interaction between the people in the photograph and the photographer; perhaps the line of vision adopted by all in the composition was under the direction of the photographer, standing at the other side of the veranda. Some people are looking into the lens, some are staring or looking in another direction, and one man turns his gaze down. Although there is little interaction, the moment the photograph is captured could be the moment in which we register-through their looksthe agency of the "others". Like other photographs in the Tropenmuseum, this photograph probably presented a harmonious picture of Bethesda, but the men hadin general-more serious-looking faces than the women, which hints of the situation's forced character. Moreover, the man in front, with his eyes downwards, seems to wish to ignore the whole performance. So in the interaction between photographer and sitters at the moment the photograph was captured, we can register something like the agency of the "other within". The performance seems forced.

The third defining moment is the circulation of the printed image as object or artefact (Edwards, 2001; Edwards \& Hart, 2004; Jordanova, 2012, p. 131). The photograph was part of a collection that was donated to the museum by H.W. Bosman from The Hague in 1917 and 1919. The collection, of photographs from the Dutch colonies in the "East" and the "West", is very diverse. So far we could not trace the journey of this specific photograph from Suriname to the collection in the Tropenmuseum, but we can give one example of the distribution of the image at the time of its making and the audiences who saw it, and that might also explain how it entered the museum collection. This photograph was reproduced in the illustrated travelogue Vier maanden in 
Suriname ("Four months in Suriname", 1915) by H. Weiss, and published by the Dutch reformed publisher Callenbach, with photo clichés made by De Bussy in Amsterdam. The photographs in the collection might have come via De Bussy since various other photographs in Weiss's travelogue ended up in the same collection.

Weiss was a protestant missionary of the Moravian Brothers, and had worked in Suriname in various capacities since 1896, among others as the Director of Bethesda. He returned to Europe when he became ill, but revisited Suriname (and Bethesda) in 1914. In his account of his visit to Bethesda, illustrated with 14 photographs (Weiss, 1915, pp. 61-72) Weiss emphasizes the modern progress visible in the institution, and underscores that today's Bethesda adheres to its policy of voluntary enrolment. The chapter is illustrated by pictures of people with leprosy, including the photograph of the shoemakers (Weiss, 1915, p. 70). Other photographs depict the infrastructure of the place (roads, school, church, houses of the European staff and nurses), the bridge providing entrance to the "lepers village", and a picture of the Steamer "Paramaribo" anchored in the Suriname river off Bethesda. Weiss does not refer to the pictures, but has added short captions to them like "view of Bethesda from the Director's house, or "Our lepers" (caption to a photograph of children climbing a tree). The photograph taken on the veranda is described as the manufacturing of shoes by lepers in Bethesda ("Het vervaardigen van schoenen door melaatschen op Bethesda").

In using this photograph as one of his illustrations, the author probably wanted to highlight one of the activities that make Bethesda "not a place of whining and complaining, no, here people are living together who know that their life, although it is still so painful, has meaning and purpose" (Weiss, 1915, p. 70, our translation). The caption puts emphasis on the working men, producing shoes. In the book's context, the picture makes especially clear how the missionary-from religious motivationframes the people he cares about as "others" who are supposed to have their own agency within the civilizing mission of both modern medical care and conversion. The travelogue, which circulated among his religious community in the Netherlands, presents the printed image as a materialization of the voluntary internal colonialism of the leprosarium within a strict colonial order (cf. Roque \& Wagner, 2012, pp. 10-11). This presentation is unchanged when one reads the caption and explanatory text to the digital image in the Tropenmuseum database.

\section{Alternative Interpretation}

By looking for the agency of the "other", we have more or less chosen the interpretative strategy that "reads colonial documents [in our case, images] against the grain", which means being critical towards the original intention (Roque \& Wagner, 2012, p. 18). Following Edwards (2001), we have tried "to identify in colonial accounts the words, visions and agency of indigenous people" (Roque
\& Wagner, 2012, p. 18). The result seems disappointing: in terms of framing, the photograph above shows all colonial agency, with slight evidence that the shoe makers are not at ease during the making of the photograph. A copy of the glass negative-inserted as an object in the Colonial Museum collection in Amsterdam-as an image in the normative travelogue of a contemporary leading missionary and as a digitized image in a collections database reinforces what we already know. At best, the analysis is critical towards the people with power and "represent[s] the subaltern [or the marginalized] in a way that is sensitive to their silence" (Spivak, quoted by Legêne, 2013, pp. 238-239). But as we asked earlier, might it be possible to get beyond sensitivity to their silence through a deeper understanding of their agency in photographs and objects? Edwards' method might help circumvent the colonial order with its fixed categories (Legêne, 2013, pp. 241-242). The investigation of visual and material sources in general can contribute to dealing with Gyan Prakash's question of “how the history of colonialism and colonialism's disciplining of history can be shaken loose from the categories and ideas it produced" (Prakash, 1994, quoted in Legêne, 2013, p. 237), and-in particular-how we go beyond the image of silent suffering.

Our disability studies approach makes evident that analyzing a photograph makes one extremely aware of categories. Because we had to describe an image in words, we became aware of the broad range of possible formulations, and therefore the contingency of the categories involved. To quote Edwards (2001, p. 20), "Photography is like ritual or theatre because it is between reality, a physical world, and imagination, dealing not only with a world of facts, but the world of possibilities". However, it also became clear that it is not easy to go beyond the fixed colonial order. By analyzing the photograph's "defining moments", the familiar categories pop up and determine our investigation. Therefore, we will recapture our case study through an alternative strategy; we will draw, inspired by ANT, the attention from the "other" to the non-human actors or things and how they interact with each other and with human actors (cf. Mak, 2012; Mol, 2002).

Let us start by looking at "leprosy" within the frame of this photograph. A disease like leprosy cannot be understood as simply existing, as Annemarie Mol has argued (Mol, 2002; Ruberg \& Clever, 2014). What leprosy is depends of the context in which it is enacted. Diseases like leprosy are multiple. At the same time, people regularly use one word for multiple enactments: they enact a disease as a "virtual common object" (Mol, 2002; Ruberg $\&$ Clever, 2014). If we look again at the photograph discussed here, leprosy is not clearly visible, but-because of the caption in Weiss' travelogue-we know the whole image is unthinkable without that virtual common object. Leprosy is the common denominator of these humans, their objects, the structures, and nature together. Without leprosy, there is no reason to build a leprosar- 
ium, to wear and make adapted shoes, to have nurses. Even though the overall context of Bethesda is religiously informed, all elements of the photograph hang around leprosy; the other way around, all these elements enact leprosy in a particular way, namely as a disease that can cause a disabled body that can still be productive. The non-human actor of the stitching machine is especially important here. In all the "defining moments" (the framing, making, and usage of the photograph) this machine, together with tools and leather, enables the enactment of the disabled body as a productive body. The sewing machine is a call to action.

By putting leprosy center stage, we emphasize the actors' interdependence (Reindal, 1999) and go beyond the questions of how independent or not the actors are, who is an active agent, and who not. The people with leprosy are in need of nurses, and the nurses are in need of people with leprosy. Our emphasis on such relations has similarities with a strategy that "is concerned with the exploration of the actual cross-cultural encounter and material practices in which colonial knowledge is grounded and embedded" (Roque \& Wagner, 2012, pp. 19-20). However, we hesitate to use here the term "cross-cultural encounters" because this is not so much about ethnic cultures as about "shared work", with the aim of "compensating for inabilities" (Winance, 2010). Our point is similar to the plea of Roque and Wagner for an "entwined reality" of "indigenous and colonial worlds" (Roque \& Wagner, 2012, p. 19), but our hesitation has to do with our reluctance to reaffirm colonial categories (as we did in our first analysis of the photograph). Plenty of images of the productive disabled body from a Western context (e.g. Van Trigt, 2013) make clear that the bodies in this picture are not (only) enacted as white and black bodies (bringing into being the colonial category of race or ethnicity), but (also) as disabled and abled bodies (bringing into being another dichotomy). There is an intersection of concepts at stake here, which was overlooked in our first analysis, and which the missionary wants us to see not as dichotomy but as rooted in common religious views.

\section{Agency}

We argue that looking for the agency of the people within this picture as "other" is not the best way to interpret this photograph. That does not mean they do not play a role of importance; on the contrary, they are-with other actors-involved in the enactment of the disabled but productive body. This complex embeddedness of actors in networks tends also to be overlooked in the historiography of disability, which focuses on tracing or granting agency. In a recent discussion about medical and disability history, Kudlick (2013, p. 551) states,

"Even if our subfields share some of the same topics, the U.S. disability history approach will always come back to two core political ideas, both rooted in the disability rights movement: a need to challenge prevail- ing assumptions about disability, and the importance of granting people with disabilities historical agency."

Kudlick's aim of "granting agency" is comparable with the search for marginalized or "other" perspectives, and isin our opinion (cf. Van Trigt, 2016, in press)-in need of an alternative. As Galis (2011) points out, the rational, independent modern subject is an important part of the disability rights movement. Independence is the prime goal because people with disabilities are often treated as dependent, in need of care. The past, as sources like photographs also tell us, tends to reflect the dependency of people with disabilities because the dominant focus of the sources emphasizes caring for people with disabilities. Although Kudlick's appeal for agency does not necessarily imply a "rational independent modern subject", it is-as Pieter Verstraete $(2007,2012)$ has argued-an important characteristic of (new) disability history.

In our approach to visual sources of the colonial past, ANT provides a good alternative, with a manysided approach, to agency because of the broad range of (non-)human actors that can be taken into account. Actors are always part of a network in which they are related to other human and non-human actors. Agency is part of these relations. Bruno Latour's advice to "follow the actors" (Latour, 2005) means that researchers might only follow the actors in power, but this is not necessarily the case. On the contrary, ANT enables a rich analysis that takes account of a broad range of actors. This approach of agency is, in our opinion, also preferable to approaches that-often inspired by Foucault - criticize the independent subject only by pointing towards ways the subject is governed.

\section{Multiplicity}

But what, exactly, does it mean that people with leprosy are involved with other actors in the enactment of the disabled, but productive body? This brings us to the question of how this photograph relates to the historic context of lepers in Bethesda, or-more generally-in Suriname. Slightly different from Edwards and Jordanova, we do not want to underline the constructed character of the photograph too much. We have no reason to doubt the (historic) events surrounding the productive body as enacted in this photograph, not only because we know from other sources that shoe manufacturing was an important activity at Bethesda to which people with leprosy contributed (Postma, 2003, pp. 74-75; Van HinteRustwijk \& Van Steenderen-Rustwijk, 2003, pp. 18-19), but also because we consider this enactment as one way "to do reality". In this photograph, we see what some people with leprosy are doing a couple of hours a day. In other (in this case, available) photographs and other sources, the bodies of people with leprosy were enacted in other ways (look for lepra/leprosy in the museum collection), thanks to other actors to which they were related and practices in which they took part. The body- 
in our opinion-has to be approached as a relational rather than natural object; categories related to the body are unstable (Mak, 2012; M'Charek, 2010). Inspired by ANT, we try to understand reality as multiple, and to approach the body in its multiplicity (Mol, 2002). Bodies and disease have to be enacted, and never simply "are"; "they appear, gain shape and are manifested through a whole range of different techniques, practices and routines" (Mak, 2012, p. 6). The consequence of understanding reality as multiple is that different realities and bodies co-exist (Mak, 2012, p. 6; Mol, 2010, p. 264).

The method we followed in the first part of the paper has the disadvantage-at least in the way we used it-of prompting the historian to construct a "real" context from the "real" looking photograph that tends (unintentionally) to reaffirm existing categories. Alternatively, if the photograph is approached using Actor-NetworkTheory (ANT, see Mol, 2010; Latour, 2005), a reality is enacted that is both made and real ( $M^{\prime}$ Charek, 2010) and co-exists with other realities. To put it less abstractly: in this photograph, the bodies of people with leprosy are enacted as productive bodies, whereas-in other photographs - the bodies of people with leprosy may be enacted as ill, or as black, or as sharing religious views with others without leprosy. The ANT assumption that the reality enacted in the photograph is both made and real prevents a simplistic interpretation (as representing a fixed historical context) and enables one to see how reality is constructed without assuming a reality behind the construction. So-for example-in our case study, one might say that the forced character of the performance-as mentioned above in analyzing the moment of making-is not forced or constructed in the sense of being coerced, but forced in the sense of having the people with leprosy stop their daily work and perform that work for distant others.

\section{Conclusion}

The central question of this article is, "How can we write histories of people with disabilities as part of the history of the 'humanitarian cloud' in a way that goes beyond the dominant image of people with disabilities as marginalized people who suffer silently and have no agency?" We have argued that existing methods that trace the agency of subalterns tend to underline existing categorizations and consequently underline (even if critically) the image of a people who have no unmediated voice in history. Moreover, it was difficult to address the concept of disability through existing methods. Nevertheless, as we argued in the second part of our article, the heuristic use of ANT can help address disability in the history of humanitarianism and overcome the dominant image of people with disabilities as lacking agency. Our case study has shown a practice that should not only be understood through the dichotomy between active and white, on the one hand, and passive and black on the other (Edwards, 2014, p. 173). Instead, it shows how - at the beginning of the twentieth century-some people with leprosy in Suriname were, by manufacturing adapted shoes, enacting their bodies just as did disabled people in - for examplethe Netherlands. Therefore, if we look at the intersection of concepts, and we take into consideration the possibility of agency within the network of humans and nonhumans, photographs are more than worthy of our investigation. Probably they cannot deliver a final answer to Gyan Prakash's question on shaking loose colonialism's history and colonialism's disciplining of history in its produced categories and ideas. However, photographs have the potential to destabilize existing categories and ideas, since they allow for so many perspectives on the "humanitarian cloud" around human rights. They underline and make visible that approaching the non-human as more than just context, but also as co-constitutive of mutual dependencies, will thoroughly affect the history of the humanitarian cloud.

\section{Acknowledgements}

The first author acknowledges the support of the ERC Consolidator Grant Rethinking Disability under grant agreement number 648115 .

\section{Conflict of Interests}

The authors declare no conflict of interests.

\section{References}

Bradley, M. P. (2014). American vernaculars: The United States and the global human rights imagination. Diplomatic History, 38(1), 1-21.

Brégain, G. (2016). Colonialism and disability: The situation of blind people in colonised Algeria. Alter: European Journal of Disability Research, 10, 149-167.

Buckingham, J. (2002). Leprosy in colonial South India: Medicine and confinement. Houndmills, UK: Palgrave.

Charlton, J. (1998). Nothing about us without us. Disability oppression and empowerment. Berkeley, Los Angeles and London: University of California Press.

Edwards, E. (2001). Raw histories: Photographs, anthropology and museums. Oxford: Berg.

Edwards, E. (2014). Photographic uncertainties: Between evidence and reassurance. History and Anthropology, 25(2), 171-188.

Edwards, E. (2016). Anthropology and photography: A long history of knowledge and affect. Photographies, 8(3), 235-252.

Edwards, E., \& Hart, J. (Eds.). (2004). Photographs objects stories: On the materiality of the image. Chicago: University of Chicago Press.

Fehrenbach, H., \& Rodogno, D. (Eds.). (2015). Humanitarian photography: A history. New York: Cambridge University Press.

Galis, V. (2011). Enacting disability: How can science and 
technology studies inform disability studies? Disability \& Society, 26(7), 825-838.

Hutchison, E. (2014). A global politics of pity? Disaster imagery and the emotional construction of solidarity after the 2004 Asian tsunami. International Political Sociology, 8, 1-19.

Jordanova, L. (2012). The look of the past. Visual and material evidence in historical practice. Cambridge: Cambridge University Press.

Kudlick, C. J. (2003). Disability history: Why we need another "other". The American Historical Review, 108(3), 763-793.

Kudlick, C. J. (2013). Comment: On the borderland of medical and disability history. Bulletin of the History of Medicine, 87(2), 540-559.

Laqua, D. (2014). Inside the humanitarian cloud: Causes and motivations to help friends and strangers. Journal of Modern European History, 12(2), 175-185.

Latour, B. (2005). Reassembling the social. An introduction to Actor-Network-Theory. Oxford: Oxford University Press.

Legêne, S. (2013). De verbeelding van de Surinaamse geschiedenis. Een postkoloniale benadering van materiële en visuele bronnen. In Maurits S. Hassankhan, Jerome L. Egger, \& Eric R. Jagdew (Eds.), Explorations in the historiography of Suriname. From colonial history to history of the people (pp. 229-246). Paramaribo: Anton de Kom Universiteit van Suriname.

Legêne, S. (2014). Mallaby's car: Colonial subjects, imperial actors, and the representation of human suffering in post-colonial exhibitions. Open Arts Journal, 3, 97-111.

Livingston, J. (2006). Insights from an African history of disability. Radical History Review, 94, 111-126.

Longmore, P. L., \& Umansky, L. (Eds.). (2001). The new disability history: American perspectives. New York: New York University Press.

Lydon, J. (2016). Photography, humanitarianism, empire. New York and London: Bloomsbury Academic.

Mak, G. (2012). Doubting sex: Inscriptions, bodies and selves in nineteenth-century hermaphrodite case histories. Manchester: Manchester University Press.

Maxwell, A. (2008). Picture imperfect. Photography and eugenics 1870-1940. Portland: Sussex Academic Press.

M'Charek, A. (2010). When whiteness becomes a problem: (Un)doing differences in the case of Down's Syndrome. Medische antropologie. Tijdschrift over gezondheid en cultuur, 22(2), 263-275.

Meekosha, H. (2011). Decolonising disability. Thinking and acting globally. Disability and Society, 26(6), 667682.

Menke, J., \& Menke, H. (2013). Decolonizing medical historiography in Suriname: Case study leprosy. In Maurits S. Hassankhan, Jerome L. Egger, \& Eric R. Jagdew (Eds.), Explorations in the historiography of Suriname. From colonial history to history of the people (pp. 643-656). Paramaribo: Anton de Kom Universiteit van Suriname.

Mol, A. (2002). The body multiple. Ontology in medical practice. Durham: Duke University Press.

Mol, A. (2010). Actor-Network Theorie: Sensitive terms and enduring tensions. Kölner Zeitschrift für Soziologie und Socialpsychologie, 50(1), 253-269.

Musarò, P. (2015). The banality of goodness: Humanitarianism between the ethics of showing and the ethics of seeing. Humanity: An International Journal of Human Rights, Humanitarianism, and Development, 6(2), 317-335.

Postma, J. (2003). De leprozerie Bethesda tussen 1879 en 1928. OSO, 22(1), 69-81.

Prakash, G. (Ed.). (1994). After colonialism: Imperial histories and postcolonial displacements. Princeton: Princeton University Press.

Reindal, S. M. (1999). Independence, dependence, interdependence: Some reflections on the subject and personal autonomy. Disability \& Society, 14(3), 353367.

Roque, R., \& Wagner, K. A. (2012). Introduction: Engaging colonial knowledge. In R. Roque \& K. A. Wagner (Eds.), Engaging colonial knowledge: Reading European archives in world history (pp. 1-32). Basingstoke: Palgrave Macmillan.

Ruberg, W., \& Clever, I. (2014). Beyond cultural history? The material turn, praxiography, and body history. Humanities, 3(4), 546-566.

Snelders, S. (in press). Leprosy and colonialism: Suriname under Dutch rule, 1750-1950. Manchester: Manchester University Press.

Stoler, A. L. (2009). Along the archival grain: Epistemic anxieties and colonial common sense. Princeton, $\mathrm{NJ}$ : Princeton University Press.

Van Dijk, J., Van Petten-van Charante, H., Van Putten, L., \& de Jonge, J. (2007). Augusta Curiel: Fotografe in Suriname 1904-1937. Amsterdam: KIT Publishers/Surinaams Museum.

Van Hinte-Rustwijk, D., \& Van Steenderen-Rustwijk, G. (2003). Van bedrijfsschade tot verzuilde paria naar exHansen client, OSO, 22(1), 10-20.

Van Trigt, P. (2013). Blind in een gidsland. Over de bejegening van mensen met een visuele beperking in de Nederlandse verzorgingsmaatschappij, 19201960. Hilversum: Verloren.

Van Trigt, P. (in press). Historicizing the social model: Some preliminary thoughts about the history of disability, science and politics in postwar Britain and the Netherlands. Studien des Aachener Kompetenzzentrums für Wissenschaftsgeschichte.

Verstraete, P. (2007). Towards a disabled past: Some preliminary thoughts about the history of disability, governmentality and experience. Educational Philosophy and Theory, 39(1), 56-63.

Verstraete, P. (2012). In the shadow of disability: Reconnecting history, identity and politics. Opladen: Barbara Budrich Publishers.

Vongsathorn, K. (2012). Gnawing pains, festering ulcers 
and nightmare suffering: Selling leprosy as a humanitarian cause in the British empire, c. 1890-1960. The Journal of Imperial and Commonwealth History, 40(5), 863-878.

Weiss, H. (1915). Vier maanden in Suriname. Nijkerk: Callenbach.
Winance, M. (2010). Care in practice. Practices of experimenting, tinkering with, and arranging people and technical aid. In A. Mol, I. Moser, \& J. Pols (Eds.), Care in practice: On tinkering in clinics, homes and farms (pp. 93-117). Bielefeld: Transcript Verlag.

\section{About the Authors}

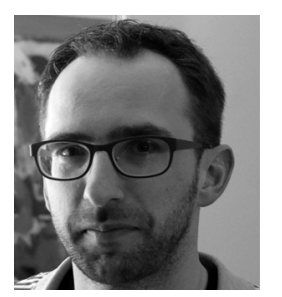

Paul van Trigt is postdoctoral researcher in the ERC-project Rethinking Disability: The Impact of the International Year of Disabled Persons (1981) in Global Perspective at the Institute of History, Leiden University. After the defence of his PhD-thesis (2013), he was lecturer political history and has worked from different angles on disability in collaboration with societal partners and researchers from the Netherlands and abroad. He has published about the modern history of the welfare state, human rights, disability and religion.

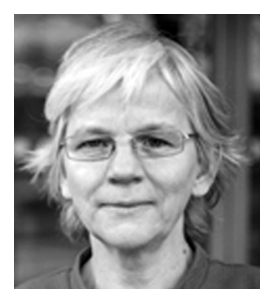

Susan Legêne is professor of Political History at the Vrije Universiteit, Amsterdam and former Head of the Curatorial Department at the Tropenmuseum in Amsterdam. She is program leader of the research program Global History, Heritage and Memory in a Post-Colonial World (www.ghhpw.com). Research focuses on European colonialism, decolonisation and its impact on issues of citizenship and belonging after 1945, with material culture and visual sources as important historical sources. With Bambang Purwanto and Henk Schulte Nordholt she edited (2015) Sites, Bodies and Stories. Imagining Indonesian History. Singapore: NUS Press. 